\title{
Profil Penilaian Hasil Belajar IPA Melalui Media Daring dan Luring pada Mid Semester di MTS Negeri 4 Mukomuko Provinsi Bengkulu
}

\author{
Peby Soraya ${ }^{1}$, Cindy Eka Putri ${ }^{2}$, Prisca Agustina Lestari ${ }^{3}$, Ahmad Walid $^{4}$ \\ 1,2,3 IAIN Bengkulu \\ ${ }^{4}$ Universitas Bengkulu
}

\begin{abstract}
Email : sorayapeby@gmail.com, cindyekaputri27@gmail.com, priscaagustina11@gmail.com, dongawalid19@gmail.com
\end{abstract}

\begin{abstract}
Abstrak
Pendidikan merupakan salah satu faktor penentu keberhasilan suatu negara, setiap perbuatan dan tindakan dalam pendidikan selalu menghendaki hasil. Artikel ini menjelaskan mengenai profil penilaian dalam pembelajaran IPA di MTsN 4 Mukomuko sebelum dan pada saat pandemic covid 2019. Profil penilaian ini diharapkan dapat memberikan masukan bagi pengembangan pembelajaran IPA berikutnya. Metode penelitian menggunakan penelitian kuantitatif deskriptif, dengan membandingkan dokumen hasil UTS peserta didik pada Maret 2020 (pembelajaran luring) dan September 2020 (pembelajaran daring). Populasi dalam penelitian ini adalah 34 orang peserta didik, dan sampel berjumlah 10 orang yaitu diambil dari 10 orang siswa berprestasi. Data penelitian dianalsis menggunakan stasistik deskriptif. Hasil penelitian menunjukkan bahwa rata-rata hasil belajar peserta didik pada pembelajaran IPA yang dilaksanakan secara luring lebih baik daripada daring. Hal ini disebabkan oleh berbagai kendala yang terjadi pada pembelajaran daring seperti Pembelajaran IPA secara daring yang diberikan guru memiliki berbagai keterbatasan yang tidak dapat menstimuli peserta didik agar berkembang imajinasinya untuk memahami materi IPA di kelas VIII peserta didik sulit mendapatkan jaringan, tidak memiliki handphone, laptop, kuota internet, faktor ekonomi orang tua, sehingga mempengaruhi motivasi belajar peserta didik. Selain itu masing-masing peserta didik memiliki gaya belajar yang berbeda-beda sehingga pembelajaran dengan penguatan dari guru tetap adalah yang terbaik.
\end{abstract}

Kata Kunci: Hasil Pembelajaran IPA, Pembelajaran Tatap Muka, Pembelajaran Online, Penilaian

\section{Abstract}

Education is one of the determining factors for the success of a country, every action and action in education always requires results. This article describes the profile of the assessment in science learning at MTsN 4 Mukomuko before and during the 2019 covid pandemic. This assessment profile is expected to provide input for the development of the next science learning. The research method uses descriptive quantitative research, by comparing the results of students' UTS results in March 2020 (offline learning) and September 2020 (online learning). The population in this study were 34 students, and the sample consisted of 10 students, which were taken from 10 outstanding students. The research data were analyzed using descriptive statistics. The results showed that the average learning outcomes of students in science learning that was carried out offline were better than online. This is due to various obstacles that occur in online learning such as online science learning provided by the teacher has various limitations that cannot stimulate students to develop their imagination to understand science material in class VIII students find it difficult to get a network, do not have cellphones, laptops, internet quota, parents' economic factors, thus affecting the learning motivation of students. In addition, each student has a different learning style so that learning with reinforcement from the teacher is still the best.

Keywords: Assessment, Science Learning Outcomes, Synchronous learning. Asynchronous learning

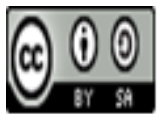

Received: November 11, 2020 Revised: December 10, 2020 Accepted: December 12, 2020 


\section{Pendahuluan}

Pendidikan merupakan salah satu faktor penentu keberhasilan suatu negara, setiap perbuatan dan tindakan dalam pendidikan selalu menghendaki hasil (Amran, 2015). Pendidik selalu berharap bahwa hasil yang diperoleh peserta didik saat ini lebih baik dan memuaskan dari hasil yang diperoleh sebelumnya. Penilaian hasil belajar sangat menentukan kemajuan kompetensi yang diperoleh oleh peserta didik. Pelaksanaan penilaian lebih jelas dijabarkan dalam Peraturan Menteri Pendidikan dan Kebudayaan RI No.23 tahun 2016 tentang Standar Penilaian Pendidikan. Pada pasal 2 ayat 1 dijelaskan bahwa penilaian pendidikan pada jenjang pendidikan dasar dan menengah terdiri atas penilaian hasil belajar oleh pendidik, penilaian hasil belajar oleh satuan pendidikan dan penilaian hasil belajar oleh pemerintah. Selain itu juga lingkup penilaian meliputi aspek sikap, pengetahuan dan keterampilan.

Penilaian (assessment) merupakan komponen penting dalam kegiatan pembelajaran. Tujuan dari penilaian untuk mengetahui tingkat ketercapaian tujuan pembelajaran dan melihat kefektifan proses belajar mengajar. (Widiana, 2016). Sistem penilaian yang baik akan mendorong pendidik untuk menentukan strategi mengajar yang baik dan memotivasi peserta didik untuk belajar yang lebih baik. Dengan demikian, secara tidak langsung pendidik juga sudah sepatutnya untuk berupaya meningkatkan kualitasnya sebagai pendidik. Pendidik merupakan sumber daya utama dari pembelajaran, sehingga penilaian terhadap hasil pembelajaran termasuk peran penting bagi kegiatan evaluasi di sekolah. (Mahirah, 2017).

Penilaian hasil belajar oleh pendidik adalah proses pengumpulan informasi atau data tentang capaian pembelajaran peserta didik dalam sikap, aspek pengetahuan, dan aspek keterampilan yang dilakukan secara terencana dan sistematis yang dilakukan untuk memantau proses, kemajuan belajar, dan perbaikan hasil belajar melalui penugasan dan penilaian hasil belajar. (Permendikbud No 53 Tahun 2015, 2015). Proses pembelajaran dikatakan berhasil apabila terjadi strukturisasi perubahan dari aspek kognitif, afektif, dan aspek psikomotorik peserta didik (Afrizal Muhardi, 2020). Hasil belajar peserta didik dapat menjadi salah satu indikator keberhasilan dalam proses pelaksanaan kegiatan pembelajaran. Kualitas pelaksanaan pembelajaran di sekolah adalah pondasi awal keberhasilan proses Pendidikan. (Sylvia et al., 2019). Semestinya asesmen dan evaluasi pendidikan berfungsi sebagai penyedia informasi dan pengendali mutu pendidikan, mencakup semua komponen pendidikan, proses pelaksanaan dan produk pendidikan secara menyeluruh, artinya asesmen merupakan suatu bagian yang terintegrasi dengan perencanaan dan proses pelaksanaan pembelajaran. (Yusuf, 2017).

Hal ini juga diperlukan dalam kegiatan pembelajaran Ilmu Pengetahuan Alam (IPA). Pembelajaran IPA merupakan suatu pembelajaran yang terkait dengan fenomena-fenomena alam semesta. Fenomena alam dalam IPA dapat ditinjau dari objek, persoalan, tema, dan tempat kejadiaanya, sehingga pembelajaran IPA adalah suatu kumpulan teori-teori yang telah diuji kebenarannya, menjelaskan tentang pola-pola dan keteraturan maupun gejala alam yang telah diamati secara seksama (Widya, dkk 2016). Proses penilaian hasil belajar IPA yang dipakai dalam kurikulum 2013 adalah penilaian autentik (Kunandar, 2013).

Adapun tujuan IPA adalah menguasai pengetahuan IPA, memahami dan menerapkan konsep IPA, menerapkan keterampilan proses, dan mengembangkan sikap. Tujuan penilaian ini sejalan dengan tiga ranah dalam kerangka kurikulum IPA yaitu (1) Penilaian Pengetahuan, pemahaman dan penerapan konsep IPA, (2) Penilaian Keterampilan dan Proses, (3) Penilaian karakter dan sikap (sikap ilmiah).

Penilaian pengetahuan IPA merupakan produk dari pembelajaran IPA. Penilaian ini bertujuan untuk melihat penguasaan peserta didik terhadap fakta, konsep, prinsip, dan hukumhukum dalam IPA dan penerapannya dalam kehidupan. Peserta didik diharapkan dapat menggunakan pemahamannya tersebut untuk membuat keputusan, berpartisipasi di masyarakat, dan menanggapi isu-isu lokal dan global. Selanjutnya penilaian keterampilan proses meliputi keterampilan dasar IPA dan keterampilan terpadu tingkat awal. Keterampilan proses IPA dasar

Jurnal Sikola: Jurnal Kajian Pendidikan dan Pembelajaran Vol. 2, No. 2, Th. 2020 
meliputi observasi, inferensi, melakukan pengukuran, menggunakan bilangan, klasifikasi, komunikasi, dan prediksi. Di samping itu, peserta didik mulai diperkenalkan dengan kemampuan melakukan percobaan sederhana dengan dua variabel atau lebih untuk menguji hipotesis tentang hubungan antar variabel. Peserta didik juga dilatih mengkomunikasikan hasil belajarnya melalui berbagai bentuk sepeti debat, diskusi, presentasi, tulisan, dan bentuk ekspresif lainnya. Kemudian penilaian sikap ilmiah meliputi sikap obyektif, terbuka, tidak menerima begitu saja sesuatu sebagai kebenaran, ingin tahu, ulet, tekun, dan pantang menyerah. Selain itu, kemampuan bekerjasama, bertukar pendapat, mempertahankan pendapat, menerima saran, dan kemampuan sosial lainnya dapat juga dilakukan melalui pembelajaran IPA.

Pada masa wabah covid-19 2020 konsep sekolah berubah drastis, perubahan terjadi dari pembelajaran yang dilaksanakan di sekolah menjadi belajar dari rumah, dengan sistem online. Berbagai inovasi pembelajaran secara besar-besaran demi mencapai suksesnya tujuan pendidikan Indonesia, yaitu untuk mengembangkan potensi peserta didik agar menjadi manusia yang beriman dan bertakwa kepada Tuhan Yang Maha Esa, berakhlak mulia, sehat, berilmu, cakap, kreatif, mandiri, dan menjadi warga negara yang demokratis serta bertanggung jawab. Begitu juga dengan pembelajaran IPA pada tingkat SMP/MTs yang diharapkan dapat menjadi wahana bagi peserta didik untuk mempelajari diri sendiri dan alam sekitar, serta prospek pengembangan lebih lanjut dalam menerapkannya di dalam kehidupan sehari-hari. Proses pembelajarannya menekankan pada pemberian pengalaman langsung untuk mengembangkan kompetensi agar menjelajahi dan memahami alam sekitar secara ilmiah.

Konsep perubahan pembelajaran pada sekolah formal di masa pendemi covid-19 tahun 2020 mengacu pada Surat Edaran (SE) Nomor 4 Tahun 2020 yang dikeluarkan oleh Menteri Pendidikan dan Kebudayaan Republik Indonesia tentang pelaksanaan kebijakan pendidikan dalam masa darurat. Proses belajar dilaksanakan di rumah melalui pembelajaran daring/jarak jauh dilaksanakan untuk memberikan pengalaman belajar yang bermakna bagi peserta didik. (Kemendikbud, 2020). Pembelajaran daring merupakan salah satu cara menanggulangi masalah penyelenggaraan pembelajaran. Pembelajaran daring adalah metode belajar yang menggunakan model interaktif berbasis internet dan learning manajemen system (LMS). (Firman, \& Rahman, 2020). Peserta didik dapat berinteraksi dengan guru menggunakan beberapa aplikasi seperti, google classroom, zoom, whatshapp group dan e-learning lainnya. Dengan pembelajaran daring peserta didik memiliki keleluasaan waktu belajar, dapat belajar dimanapun dan kapanpun. Pembelajaran ini merupakan inovasi pendidikan untuk menjawab tantangan ketersediaan sumber belajar yang variatif. Pembelajaran daring berbeda dengan pembelajaran luring.

Perbedaan proses pelaksanaan pembelajaran dari luring menjadi daring tentu saja membawa dampak bagi hasil pembelajaran peserta didik, khususnya pembelajaran IPA pada tingkat SMP/MTs. Hasil belajar yang seharusnya mampu mengukur 3 aspek, yaitu penilaian pengetahuan, penilaian keterampilan dan proses, penilaian karakter dan sikap ilmiah, menjadi focus pada penilaian pada aspek kognitif peserta didik. Selain itu pelaksanaan proses pembelajaran yang cenderung mengarah pada penugasan belum mampu mengaktifkan ke 3 aspek di atas. Untuk itu penulis melakukan penelitian mengenai perbedaan hasil belajar yang diperoleh oleh peserta didik pada pembelajaran IPA sebelum dan saat masa pandemi covid-19 tahun 2020 ini. Penelitian ini dilakukan terhadap hasil belajar IPA peserta didik di MTsN 4 Mukomuko Kota Bengkulu. Artikel ini bertujuan untuk mendeskripsikan perbedaan hasil belajar peserta didik yang diperoleh pada pembelajaran IPA secara luring dan daring, membantu guru dalam memahami peserta didik yang masih mengalami kesulitan pada pembelajaran yang telah dilakukan pada proses pembelajaran IPA. 


\section{Metode Penelitian}

Metode penelitian dalam penelitian ini adalah deskriptif kuantitatif. Data diperoleh dari dokumen penilaian pembelajaran IPA yang telah dilakukan pada saat ujian tengah semester pada Maret tahun 2020 dan September 2020 di MTsN 4 Mukomuko, Bengkulu. Penilaian UTS pembelajaran IPA pada Maret tahun 2020 diperoleh dari pembelajaran secara luring, sementara Penilaian UTS pembelajaran IPA pada September tahun 2020 diperoleh dari pembelajaran secara daring. Populasi penelitian ini adalah 34 peserta didik yang di kelas VII dan VII di MtsN 4 Mukomuko, sedangkan sampelnya adalah 10 orang peserta didik yang masuk dalam peringkat nilai sepuluh besar. Teknik pengumpulan data pada penelitian ini adalah dengan membandingkan dokumen hasil belajar IPA yang diperoleh dari hasil ujian tengah semester (UTS) pada Maret 2020 dan September 2020. Data penelitian yang telah terkumpul, dianalisis dengan menggunakan metode analisis statistik deskriptif.

\section{Hasil dan Pembahasan}

IPA merupakan konsep pembelajaran alam dan mempunyai hubungan yang sangat luas terkait dengan kehidupan manusia. Pembelajaran IPA sangat berperan dalam proses pendidikan dan juga perkembangan teknologi, karena IPA memiliki upaya untuk membangkitkan minat manusia serta kemampuan dalam mengembangkan ilmu pengetahuan dan teknologi serta pemahaman tentang alam semesta yang mempunyai banyak fakta yang belum terungkap dan masih bersifat rahasia sehingga hasil penemuannya dapat dikembangkan menjadi ilmu pengetahuan alam yang baru dan dapat diterapkan dalam kehidupan sehari-hari. Dengan demikian, IPA memiliki peran yang sangat penting. Kemajuan IPTEK yang begitu pesat sangat mempengaruhi perkembangan dalam dunia pendidikan terutama pendidikan IPA di Indonesia dan negara-negara maju.

Pendidikan IPA telah berkembang di negara-negara maju dan telah terbukti dengan adanya penemuanpenemuan baru yang terkait dengan teknologi. Akan tetapi di Indonesia sendiri belum mampu mengembangkannya. Pendidikan IPA di Indonesia belum mencapai standar yang diinginkan, padahal untuk memajukan ilmu pengetahuan dan teknologi (IPTEK) sains penting dan menjadi tolak ukur kemajuan bangsa. Kenyataan yang terjadi di Indonesia, mata pelajaran IPA tidak begitu diminati dan kurang diperhatikan.

MTsN 4 Mukomuno pada dasarnya menjalankan konsep Kurikulum 2013 sebelum terjadinya pandemi covid-19. Kemudian pola pembelajaran yang dilakukan pada masa pandemi covid-19 yang telah dimodifikasi sesuai dengan kondisi yang berkembang, sesuai Surat Edaran nomor 4 Tahun 2020 tentang pelaksanaan kebijakan pendidikan dalam masa darurat penyebaran covid-19. Masih dalam keadaan pandemi ini sesuai aturan pemerintah sekolah-sekolah masih menerapkan sekolah jarak jauh, hal tersebut juga dilakukan di MTsN 4 Mukomuno, untuk menerapkan sekolah jarak jauh memerlukan media penghubung antara peserta didik dirumah dengan para guru di sekolah. Pembelajaran luring adalah akronim dari luar jaringan, atau terputus dari jaringan computer Misalnya belajar memalui buku pengangan peserta didik atau pertemuan langsung (Malyana, 2020).

Pembelajaran daring merupakan sistem Pendidikan jarak jauh dengan sekumpulan metode pengajaran dimana terdapat aktivitas pengajaran yang dilaksanakan secara terpisah dari aktifitas belajar. Pembelajaran daring diselenggarakan melalui jaringan internet (Fitri, dkk, 2020). Hasil analisis deskriptif data hasil belajar 10 orang peserta didik berprestasi pada UTS IPA kelas VII pada Maret 2020 dapat dilihat pada tabel di bawah ini 
Tabel. 1 Hasil UTS IPA Siswa Berprestasi Pada Kelas VII di MTS Negeri 4 Mukomuko dengan Pembelajaran Luring

\begin{tabular}{clc}
\hline No & Nilai UTS IPA (Pembelajaran Luring -Maret 2020 & Nilai Luring \\
\hline $\mathbf{1}$ & Acha Tri Putri & 85 \\
\hline $\mathbf{2}$ & Aliya Miranti & 82 \\
\hline $\mathbf{3}$ & Amru Rahul & 78 \\
\hline $\mathbf{4}$ & Afdal Dinilhaq & 82 \\
\hline $\mathbf{5}$ & Deca Afriliya & 81 \\
\hline $\mathbf{6}$ & Gaffa Albiruni Mashori & 81 \\
\hline $\mathbf{7}$ & Hadra Zoni & 80 \\
\hline $\mathbf{8}$ & Keni Anggraini & 70 \\
\hline $\mathbf{9}$ & Kevin Sanjaya & 82 \\
\hline $\mathbf{1 0}$ & Kiki Prayoga & 78 \\
\hline
\end{tabular}

IPA di atas KKM setelah mengikuti pembelajaran IPA tatap muka pada periode Januari - Maret 2020. Proses pembelajaran IPA menekankan pada pemberian pengalaman langsung untuk mengembangkan kompetensi agar menjelajahi dan memahami alam sekitar secara ilmiah. (Chan, 2017). Salah satu ilustasi yang mampu memberikan penjelasan kepada peserta didik ialah demonstrasi. (Fatimah, 2017). Selama proses pembelajaran tatap muka (luring), guru menggunakan buku sumber sebagai acuan dan alam sekitar untuk pengamatan langsung.

Pandemi covid-19 telah mengubah jalan hidup hampir semua populasi di dunia, termasuk pada dunia Pendidikan. (Rachmawati, Y., Ma'arif, M., Fadhillah, N., Inayah, N., Ummah, K., Siregar, M. N., Auliyah, 2020). Corona virus cepat menyebar dengan masa inkubasi rata-rata 56 hari dengan masa inkubasi terpanjang 14 hari. (Yurianto, Ahmad, Bambang Wibowo, 2020). Setiap negara memiliki akhiran yang berbeda terkait wabah corona virus. Hal ini berkaitan dengan kebijakan yang telah ditetapkan serta kesiapsiagaan pemerintah guna meminimalkan penyebarannya. (Lee, 2020). Physical distancing (pembatasan interaksi) merupakan salah satu cara memutus rantai penyebaran covid-19, yaitu dengan pembatasan interaksi masyarakat. (Mustakim, 2020). Dunia pendidikan ikut merasakan dampak dari adanya Pandemi covid-19. Adanya pandemi covid-19 membuat pembelajaran tatap muka secara konvensional tidak mungkin dilakukan di berbagai daerah. Hal ini memaksa dilaksanakannya pengajaran jarak jauh yang sebelumnya belum pernah dilaksanakan secara serentak. (Sun, L., Tang, Y., \& Zuo, 2020). Sekolah dituntut tetap mampu memberikan layanan standar minimum kepada pemangku kepentingannya di tengah Work From Home (WFH) dan Pembatasan Sosial Berskala Besar (PSBB) (Murfi, Ali. Fathurrochman, 2020). Pembelajaran daring menjadi salah satu alternatif dalam mengatasi permasalahan tersebut (Ali Sadikin, 2020). Pembelajaran secara daring merupakan solusi untuk melaksanakan pembelajaran meskipun pendidik dan peserta didik berada pada lokasi yang berbeda (Verawardina, U., Asnur, L., Lubis, A. L., \& Hendriyani, 2020).

Pembelajaran IPA secara daring di MTsN 4 Mukomuko melalui aplikasi google classroom dan whatsaap grup untuk membantu proses komunikasi. Guru menggunakan kedua aplikasi ini sebagai aplikasi pembelajaran online dengan dibantu video demontrasi pada beberapa materi yang membutuhkan praktik. Materi pembelajaran diberikan guru kepada peserta didik melalui aplikasi tersebut dalam bentuk power point, materi bacaan, dan video demontrasi singkat. Tabel berikut menunjukkan nilai UTS IPA 10 orang siswa berprestasi setelah pembelajaran dilakukan secara daring pada Juli-September 2020. 
Tabel. 2 Hasil UTS IPA Siswa Berprestasi Pada Kelas VIII di MTS Negeri 4 Mukomuko dengan Pembelajaran Daring

\begin{tabular}{lc}
\multicolumn{1}{c}{$\begin{array}{c}\text { Nilai UTS IPA } \\
\text { (Pembelajaran Daring -September 2020 }\end{array}$} & Nilai Daring \\
\hline Acha Tri Putri & 83 \\
\hline Aliya Miranti & 80 \\
\hline Amru Rahul & 76 \\
\hline Afdal Dinilhaq & 80 \\
\hline Deca Afriliya & 79 \\
\hline Gaffa Albiruni Mashori & 79 \\
\hline Hadra Zoni & 85 \\
\hline Keni Anggraini & 73 \\
\hline Kevin Sanjaya & 80 \\
\hline Kiki Prayoga & 80 \\
\hline
\end{tabular}

Data di atas memperlihatkan bahwa terjadi perbedaan hasil UTS peserta didik setika mengikuti pembelajaran IPA secara luring (kelas VII) dan pembelajaran daring (kelas VIII). Ada peserta didik yang mengalami pengingkatan dan penurunan. Profil perbandingan hasil belajar IPA (nilai UTS) peserta didik setelah mengikuti pembelajaran muring dan daring dapat dilihat pada tabel di bawah ini.

Tabel. 3 Profil Perbedaan Hasil Belajar IPA Siswa Berprestasi Pada Kelas VII dan VIII di MTS Negeri 4 Mukomuko dengan Pembelajaran Luring dan Daring

\begin{tabular}{|c|c|c|c|c|c|}
\hline No & $\begin{array}{c}\text { Nilai UTS IPA } \\
\text { (Pembelajaran Luring) }\end{array}$ & $\begin{array}{l}\text { Nilai } \\
\text { Luring }\end{array}$ & $\begin{array}{c}\text { Nilai UTS IPA } \\
\text { (Pembelajaran Duaing) }\end{array}$ & $\begin{array}{c}\text { Nilai } \\
\text { Daring }\end{array}$ & Selisih \\
\hline 1 & Acha Tri Putri & 85 & Acha Tri Putri & 83 & -2 \\
\hline 2 & Aliya Miranti & 82 & Aliya Miranti & 80 & -2 \\
\hline 3 & Amru Rahul & 78 & Amru Rahul & 76 & -2 \\
\hline 4 & Afdal Dinilhaq & 82 & Afdal Dinilhaq & 80 & +2 \\
\hline 5 & Deca Afriliya & 81 & Deca Afriliya & 79 & -2 \\
\hline 6 & Gaffa Albiruni Mashori & 81 & $\begin{array}{ll}\text { Gaffa } & \text { Albiruni } \\
\text { Mashori } & \end{array}$ & 79 & +2 \\
\hline 7 & Hadra Zoni & 80 & Hadra Zoni & 85 & +5 \\
\hline 8 & Keni Anggraini & 70 & Keni Anggraini & 73 & +3 \\
\hline 9 & Kevin Sanjaya & 82 & Kevin Sanjaya & 80 & -2 \\
\hline 10 & Kiki Prayoga & 78 & Kiki Prayoga & 80 & +2 \\
\hline & Nilai tertinggi & 85 & Nilai tertinggi & 85 & \\
\hline & Nilai terendah & 70 & Nilai terendah & 73 & \\
\hline & Rata-rata & 79,9 & Rata-rata & 79,5 & $-0,04$ \\
\hline
\end{tabular}

Perbedaan hasil belajar peserta didik pada pembelajaran IPA yang dilihat dari nilai UTS 10 orang peserta didik setelah mengikuti pembelajaran luring dan daring tidak jauh berbeda. Namun terlihat rata-rata hasil belajar setelah mengikuti pembelajaran daring lebih rendah daripada peserta didik mengikuti pembelajaran luring. 
Berdasarkan hasil wawancara, nilai peserta didik dapat menurun akibat dari, 1). Kurangnya motivasi belajar dan rasa percaya diri. Pada kenyataannya tidak semua individu memilki rasa percaya diri yang tinggi, dan kurangnya rasa percaya diri yang tinggi juga merupakan gejala khas yang banyak menimpa setiap orang, apalagi dalam masa bersekolah. (Walid Ahmad, 2019). 2). Peserta didik tidak memiliki kuota internet. 3). Peserta didik tidak memiliki fasilitas seperti handphone dan laptop karena faktor ekonomi. Status sosial ekonomi orang tua tentunya akan mendukung fasilitas belajar anak yang diperlukan. Dengan fasilitas belajar anak yang terpenuhi maka kemudahan belajar bagi anak akan tercipta motivasi belajar dan akan memiliki prestasi belajar yang lebih baik. Status sosial ekonomi orang tua yang rendah bisa menyebabkan prestasi belajar peserta didik menjadi rendah pula. (W.S, 2006)

Belajar bukan menghafal dan bukan pula mengingat. Belajar adalah suatu proses yang ditandai dengan adanya perubahan pada diri seseorang. Perubahan sebagai hasil proses belajar dapat ditunjukkan dalam berbagai bentuk seperti berubah pengetahuannya, pemahamannya, sikap dan tingkah lakunya, keterampilannya, kecakapan dan kemampuannya, daya reaksinya, daya penerimaannya dan lain-lain aspek yang ada pada individu. Oleh sebab itu, belajar adalah proses yang aktif, belajar adalah proses mereaksi terhadap semua situasi yang ada di sekitar individu. Belajar adalah proses yang diarahkan kepada tujuan proses berbuat melalui berbagai pengalaman. Belajar adalah proses melihat, mengamati, memahami sesuatu. Apabila kita berbicara tentang belajar maka kita berbicara bagaiman mengubah tingkah laku seseorang. Keberhasilan pengajaran dapat dilihat dari segi hasil. Asumsi dasar ialah proses pengajaran yang optimal memungkinkan hasil belajar yang optimal pula. Ada korelasi antara proses pengajaran dengan hasil yang dicapai. Makin berusaha untuk menciptakan kondisi proses pengajaran,makin tinggi pula hasil atau produk dari pengajaran itu. Salah satu lingkungan belajar yang paling dominan mempengaruhi hasil belajar di sekolah ialah kualitas pengajaran. (Sudjana, 2011)

Pembelajaran IPA yang baik adalah proses pembelajaran yang menumbuhkan motivasi siswa dalam belajar, sehingga siswa dapat belajar secara aktif, dan mendapatkan pengalaman belajar yang menyenangkan, sehingga tujuan pembelajaran dapat tercapai. Pembelajaran tidak hanya didasarkan pada pengetahuan siswa terhadap teori, namun pembelajaran dapat memberikan siswa pemahaman untuk mengaitkan antara teori dan kehidupan nyata. Sehingga siswa tidak hanya pintar dalam teori namun juga pintar dalam mengaplikasikannya dalam kehidupan sehari-hari. Keberhasilan proses pembelajaran IPA ditandai dengan tercapainya semua tujuan pembelajaran yang terlihat dalam hasil belajar IPA peserta didik. Dalam belajar IPA siswa tidak cukup hanya mengetahui informasi yang ada di buku, tapi siswa juga harus melakukan serangkaian kegiatan untuk memberikan pengalaman langsung kepada peserta didik tentang informasi tersebut.

Pada awal penerapannya, banyak peserta didik yang menanggapi pembelajaran daring ini dengan baik, namun, setelah berjalannya proses pembelajaran secara daring tersebut, banyak peserta didik mengalami kesulitan dalam belajar. Dari hasil wawancara dengan informan menunjukkan bahwa dengan metode pembalajaran secara daring, pada pembelajaran IPA dirasa kurang kondusif. Adapun faktor yang dikeluhkan oleh peserta didik adalah faktor susahnya menyampaikan materi oleh guru dan susahnya memahami materi oleh peserta didik, masalah lain yang dihadapi oleh informan yaitu jaringan yang kadang terputus sehingga proses belajar tidak dapat dilakukan secara lancar. Selain faktor jaringan, keterbatasan sebagian peserta didik dan/atau orang tua peserta didik dalam membeli data internatan menjadi salah satu kendala sehingga proses pembelajaran daring kurang efektif. Sehingga dengan demikian, penerapan aplikasi Zoom maupun aplikasi yang menggunakan data internetan tidak dapat diterapkan dalam proses pembelajaran IPA pada MTsN 4 Mukomuko.

Perbandingan nilai UTS IPA peserta berprestasi di MTsN 4 Mukomuko di atas memperlihatkan pembelajaran dengan metode daring tidak sefektif dengan proses pembelajaran di kelas. Hal tersebut terbukti dari hasil UTS mereka dan tanggapan peserta didik yang merasa 
sulit memahami jika materi tersebut berkaitan dengan materi yang mengharuskan mereka membayangkan benda alam tanpa penjelasan tanya jawab dengan guru untuk mendapatkan penguatan. Selanjutnya, menurut peserta didik MTsN 4 Mukomuko, proses pembelajaran daring terkadang terganggu dengan aktivitas lain yang tak terduga di dalam rumah. Misalnya peserta didik harus membantu pekerjaan orang tua dan jadwal belajar telah dimulai dan aktivitasaktivitas lain yang berpeluang mengganggu konsentrasi ketika proses belajar sedang berlangsung. Dari berbagai gambaran mengenai kendala yang dihadapi oleh guru maupun peserta didik dalam pembelajaran secara daring di atas menunjukkan bahwa proses pembelajaran dalam kelas lebih efektif dibandingkan dengan proses pembelajaran tanpa tatap muka secara langsung.

\section{Kesimpulan}

Perubahan metode penyampaian dalam proses pembelajaran IPA dari pembelajaran tatap muka (luring) menjadi pembelajaran berbasis jaringan (daring) memiliki implikasi terhadap perolehan hasil belajar peserta didik di MTsN 4 Mukomuko Bengkulu. Pembelajaran IPA secara daring yang diberikan guru memiliki berbagai keterbatasan yang tidak dapat menstimuli peserta didik agar berkembang imajinasinya untuk memahami materi IPA di kelas VIII. Selain itu juga ada kendala lainnya secara ekternal yang membatasi peserta didik tidak optimal dalam pembelajaran daring, seperti amsalah jaringan, keterbatasan sarana dan prasarana dan orang tua.

\section{Daftar Pustaka}

Afrizal Muhardi, I. S. (2020). Pelaksanaan Penilaian Autentik dalam Pembelajaran Sosiologi Kelas X di SMA Negeri 1 Lubuk Basung. Jurnal Sikola: Jurnal Kajian Pendidikan Dan Pembelajaran, 2(2), 70-84. https://doi.org/https://doi.org/10.24036/sikola.v2i2.87

Ali Sadikin, A. H. (2020). Pembelajaran Daring di Tengah Wabah Covid-19. BIODIK: Jurnal Ilmiah Pendidikan Biologi, 6(2), 214-224.

Amran. (2015). Faktor penentu Keberhasilan Pengelolaan Satuan Pendidikan. Manajer Pendidikan, 9(2), 185-196.

Chan, F. (2017). Implementasi Guru Menggunakan Metode Permainan Pada Pelajaran IPA di Sekolah. Jurnal Gentala Pendidikan Dasar, 2(1), 106-123. https://doi.org/https://doi.orG/10.22437/gentala.v2I1.6821

Fatimah. (2017). Meningkatkan Hasil Belajar Siswa Dalam Pembelajaran IPA dengan Metode Demonstrasi Dikelas V SDN 10 Biau. Jurnal Kreatif Tadulako Online, 5(4), 85-96.

Firman, \& Rahman, S. R. (2020). Pembelajaran Online di Tengah Pandemi Covid-19. IJES: Indonesian Journal Of Education Science, 2(2). https://doi.org/https: //doi.org/ 10.31605 /ijes.v2i2.659

Permendikbud no 53 Tahun 2015, (2015).

Kemendikbud. (2020). SE Mendikbud Nomor 4 Tahun 2020 tentang Pelaksanaan Kebijakan Pendidikan dalam Masa Darurat Penyebaran Covid-19.

Kunandar. (2013). Penilaian Autentik. Raja Grafindo Persada.

Lee, A. (2020). Wuhan novel coronavirus (COVID-19): why global control is challenging? Public Health, January, 19-21. https://doi.org/https://doi.org/https://doi.orG/10.1016/j.puh e.2020.02.001

Mahirah. (2017). Evaluasi Belajar Peserta Didik. Jurnal Idaarah, 1(2), 257-267.

Jurnal Sikola: Jurnal Kajian Pendidikan dan Pembelajaran Vol. 2, No. 2, Th. 2020 
Murfi, Ali. Fathurrochman, I. A. N. S. J. (2020). Kepemimpinan Sekolah dalam Situasi Krisis Covid-19 di Indonesia. Manageria: Jurnal Manajemen Pendidikan Islam, 5(1), 121.

Mustakim. (2020). Efektivitas Pembelajaran Daring Menggunakan Media Online selama pandemi Covid-19 pada Mata Pelajaran Matematika. Al Asma: Journal of Islamic Education, 2(1), 1-11.

Rachmawati, Y., Ma'arif, M., Fadhillah, N., Inayah, N., Ummah, K., Siregar, M. N., Auliyah, A. (2020). Studi Eksplorasi Pembelajaran Pendidikan IPA Saat Masa Pandemi COVID-19 di UIN Sunan. Indonesian Journal of Science Learning, 1(1), 32036.

Sudjana, N. (2011). Penilaian Hasil dan Proses Belajar Mengajar. Rosda Karya.

Sun, L., Tang, Y., \& Zuo, W. (2020). Coronavirus pushes education online. Nature Materials. https://doi.org/https://doi.orG/10.1038/s41563-020-0678-8

Sylvia, I., Anwar, S., \& Khairani, K. (2019). Pengembangan Instrumen Penilaian Autentik Berbasis Pendekatan Authentic Inquiry Learning Pada Mata Pelajaran Sosiologi di Sekolah Menengah Atas. SOCIUS, 6(2), 103. https://doi.org/10.24036/scs.v6i2.162

Verawardina, U., Asnur, L., Lubis, A. L., \& Hendriyani, Y. (2020). Reviewing Online Learning Facing the Covid-19 Outbreak. 12(3), 385-392.

W.S, Winkel. (2006). Psikologi Pengajaran. Grafindo.

Widiana, I. W. (2016). Pengembangan Asesmen Proyek dalam Pembelajaran IPA di Sekolah Dasar. Jurnal Pendidikan Indonesia, 5(2). https://doi.org/http://dx.doi.org/10.23887/jpiundiksha.v5i2.8154

Yurianto, Ahmad, Bambang Wibowo, K. P. (2020). Pedoman Pencegahan dan Pengendalian Coronavirus Disease (COVID-19).

Yusuf, A. M. (2017). Asesmen dan Evaluasi Pendidikan Pilar Penyedia Informasi dan Kegiatan Pengendalian Mutu Pendidikan. Kencana. 